\title{
PEMODELAN PENGERINGAN KUNYIT (CURCUMA DOMESTICA VAL.) BERBASIS MACHINE VISION DENGAN MENGGUNAKAN ARTIFICIAL NEURAL NETWORK
}

\section{Modelling of Turmeric (Curcuma Domestica Val.) Drying Using Machine Vision and Artificial Neural Network}

\author{
Muchammad Zakaria*, Yusuf Hendrawan, Gunomo Djojowasito \\ Jurusan Keteknikan Pertanian - Fakultas Teknologi Pertanian - Universitas Brawijaya \\ Jl. Veteran, Malang 65145 \\ *Penulis Korespondensi: email: muchammadzakaria86@gmail.com
}

\begin{abstract}
ABSTRAK
Pengeringan pada kunyit (Curcuma Domestica Val.) bertujuan untuk memperpanjang umur simpan serta mengurangi kadar air hingga batas perkembangan mikroorganisme dan kegiatan enzim yang menyebabkan pembusukan menjadi terhambat. Saat ini, pengeringan kunyit menggunakan sinar matahari dan alat pengering mekanis dengan kontrol waktu dan suhu. Banyaknya kendala pada proses pengeringan meyebabkan dibutuhkannya suatu teknologi yang dapat memonitoring kadar air dari kunyit secara pasti dan akurat, yaitu dengan mesin pengering berbasis machine vision dan artificial neural network (ANN). Tujuan penelitian untuk mengetahui waktu terbaik untuk pengeringan kunyit berbasis machine vision dengan menggunakan ANN, mengetahui perbedaan grafik ANN untuk gambar yang memenuhi syarat kadar air standar pengeringan kunyit, mengetahui ANN terbaik dalam proses pengeringan kunyit. Penelitian ini menggunakan metode deskriptif yang terdiri dari lama waktu pengeringan yaitu 5 jam dengan 5 kali pengulangan dan menggunakan bahan kunyit. Metode aplikasi mesin pengering yang dilengkapi dengan machine vision sebagai pengambil data gambar pada bahan, kemudian di ekstrak warnanya untuk mengetahui nilai (red, green, dan blue). Proses pembangunan model ANN digunakan learning rate sebesar $0.1,0.2,0.3,0.4$, dan 0.5 pada momentum rate sebesar $0.5,0.6,0.7,0.8$, dan 0.9 . Hasil learning process terbaik adalah learning rate 0.3 dan momentum rate 0.9 . Model ANN dengan nilai error terendah yaitu untuk training 0.005 MSE, dan 24.59\% ARE (Average Error), untuk validasi 0.005 MSE dan 25.35\% ARE
\end{abstract}

Kata kunci : Artificial Neural Network, Kunyit, Kadar Air, Machine Vision

\begin{abstract}
To maintain turmeric (Curcuma domestica Val.) to be durable is by drying. The purpose of drying to reduce the moisture content up to limit the development of microorganisms and enzyme activities that cause spoilage. Nowadays, turmeric drying is using sunlight and mechanical drier with time and temperature control. However, drying process often arise various problems, therefore require a technology to monitor the moisture content of turmeric definitively and accurately, that is using drying machine-based machine vision and ANN (Artificial Neural Network). The purpose of this study to determine the best time for drying turmeric-based machine vision by using ANN, to know the difference of ANN's graph for image that qualify the standard of moisture content in drying turmeric, to know the best ANN in the turmeric drying process. This research use descriptive method that consisted of duration of drying time, 5 hours with five repetitions. The application of drying machine equipped with a machine vision is to take data image on the materials, then color was extracted to know the value of (red, green, and blue). In the development process of ANN model, use learning rate of 0.1, 0.2, 0.3, 0.4, and 0.5 on the momentum rate of 0.5, 0.6, 0.7, 0.8 , and 0.9. Best results is showed on the learning process of learning rate 0.3 and momentum rate 0.9. ANN models with the lowest error value is for training 0005 MSE and 24.59\% ARE, for validation MSE 0005 and $25.35 \%$ ARE
\end{abstract}

Keywords: Artificial Neural Network, Turmeric, Moisture, Machine Vision 


\section{PENDAHULUAN}

Indonesia merupakan negara yang memiliki kekayaan hayati luar biasa, terdapat 40000 jenis tumbuhan dan diantaranya sekitar 1300 tumbuhan tersebut dapat dimanfaatkan sebagai obat tradisional (WWF, 2009). Berdasarkan potensi yang ada produk obat dapat dikembangkan secara luas, salah satu jenis tanaman yang berpotensi adalah kunyit (Box, 1989; Rahayu, 2010; Hee Kim et al., 2016; Lee Yue et al., 2016). Semakin berkembangnya obat tradisional, kosmetik, makanan dan minuman kesehatan, serta industri jamu banyak bergantung kepada bahan aktif yang terkandung di dalam kunyit (Man et al., 2015; Shin et al., 2015; Harsha et al., 2016). Porsi yang paling besar dalam penggunaan simplisia kunyit terjadi pada pembuatan obat tradisional (Syukur, 2010).

Kunyit merupakan tanaman suku temu-temuan dengan nama latin Curcuma longa Koen atau Curcuma domestica Val. senyawa utama yang terkandung dalam rimpang kunyit adalah senyawa kurkuminoid. Senyawa kurkuminoid yang memberikan warna kuning pada kunyit. Kurkuminoid menjadi pusat perhatian para peneliti yang mempelajari keamanan, sifat antioksidan, antiinflamasi, efek pencegah kanker, ditambah kemampuannya menurunkan resiko serangan jantung (Asghari et al., 2009). Zat yang terkandung dalam kunyit adalah kandungan lemak 1-3\%, karbohidrat $3 \%$, protein $30 \%$, pati $8 \%$, vitamin C $45-55 \%$, zat besi, fosfor, dan kalsium. Curcumin (1,7-bis (4-hidroksi-. 3-metoksifenil)-1E,6Eheptadiene-3,5-dione atau diferuloyl metan), yang dihasilkan dapat digunakan sebagai obat pada penyakit diabetes dan gagal ginjal (Trujillo et al., 2013). Pengeringan dilakukan untuk mempertahankan kunyit agar tetap tahan lama. Pengeringan merupakan terjadinya penguapan air ke udara karena perbedaan kandungan uap air antara udara dengan bahan yang dikeringkan (Siallagan, 2009; Yao, 2016; Xie et al., 2017). Pengeringan juga bertujuan untuk mengurangi kadar air bahan sampai batas perkembangan mikroorganisme dan kegiatan enzim yang dapat menyebabkan pembusukan terhambat atau bahkan terhenti sama sekali (Morgan et al., 2006; Fadilah et al., 2010; Lorentzen et al., 2015). Dengan demikian, bahan yang dikeringkan mempunyai waktu simpan lebih lama (Adawyah, 2008; Sangwan et al., 2012; Chan et al., 2013).
Keuntungan yang diperoleh dengan mengunakan pengering buatan yakni kondisi pengeringan terkontrol dan waktu pengeringan bisa lebih cepat dengan tidak bergantung oleh cuaca, sehingga menghasilkan produk yang berkualitas baik (Boniglia et al., 2009; Asriyanti, 2013; Schaarschmidt, 2016). Ciri-ciri waktu pengeringan sudah berakhir apabila simplisia dapat dipatahkan dengan mudah dengan kadar air $\pm 8-10 \%$. Kualitas simplisia dengan kadar air tersebut cukup baik untuk pengolahan lebih lanjut dan penyimpanan (Dhanalakshmi dan Bhattacharya, 2014; Borah et al., 2015; Kusumaningrum et al., 2015; Hmar et al., 2017).

Teknologi pengeringan berbasis machine vision mampu memprediksi kadar air dari kunyit secara akurat dan presisi berdasarkan pemodelan pada proses pengeringan kunyit, sehingga dapat diterapkan di industri obat tradisional (Khazaei et al., 2013; Khalili et al., 2014; Nadian et al., 2017; Xu, 2017). Tujuan Penelitian adalah mengetahui waktu terbaik pengeringan kunyit berbasis machine vision dengan mengunakan ANN, mengetahui perbedaan grafik ANN gambar yang memenuhi syarat kadar air standar pada proses pengeringan kunyit, mengetahui ANN terbaik dalam proses pengeringan kunyit.

\section{BAHAN DAN METODE}

\begin{abstract}
Alat
Peralatan yang digunakan dalam penelitian ini adalah alat perajang, baskom sebagai tempat bahan perlakuan, mesin pengering MI ITEM dan web camera 8 MPA sebagai pengambil data gambar, lampu Philips 5 watt dengan intensitas cahaya 186.54 lux, timbangan digital, laptop untuk menyimpan data gambar, oven Heraeus type T 5058. Adapun rangkaian keseluruhan alat yang digunakan dapat dilihat pada Gambar 1.
\end{abstract}

\section{Bahan}

Bahan yang digunakan dalam penelitian ini adalah kunyit (Curcuma domestica Val.) dengan umur panen 12 bulan yang diperoleh dari wilayah kota Batu.

\section{Metode}

Penelitian dilaksanakan berbasis machine vision sebagai pengambilan data gambar menggunakan kamera web sebagai pengambil gambar dari kunyit. Selanjutnya gambar 
di ekstrak nilai red, gray, blue (RGB) menggunakan software Visual Basic 6.0 (VB6), kemudian hasil data tersebut di analisa menggunakan metode ANN untuk mendapatkan hubungan antara gambar dan kadar air dari kunyit yang berupa model matematika yang akan menghasilkan grafik training ANN dan grafik validasi ANN. Proses pengeringan dilakukan pada suhu $70{ }^{\circ} \mathrm{C}$, dimana pada suhu tersebut proses pengeringan terjadi optimal (Plotto, 2004; Prasad et al., 2006; Hmar et al., 2017).

Pengambilan data gambar saat pengeringan dilakukan 1 menit sekali. Machine vision akan mengambil foto dan menyimpannya ke dalam laptop. Penimbangan massa kunyit selama 1 menit sekali dilakukan untuk mengetahui kadar air kunyit, sehingga didapatkan hasil perubahan massa suatu bahan. Hasil tersebut kemudian di interpolasi dengan kadar air awal kunyit sebelum pengeringan dan sesudah pengeringan, yaitu kadar air awal dengan rata-rata $85.28 \%$ dan kadar air akhir dengan rata-rata $5.42 \%$, serta variasi learning rate $0.1,0.2,0.3,0.4$, dan 0.5 pada momentum rate yaitu $0.5,0.6,0.7,0.8$, dan 0.9. Diagram alir proses kerja penelitian dapat dilihat pada Gambar 2.

\section{HASIL DAN PEMBAHASAN}

Hubungan Kadar Air Kunyit (Curcuma domestica Val.) Selama Proses Pengeringan Proses pengeringan dalam penelitian ini dilakukan selama 5 jam dengan 5 kali ulangan. Analisa kadar air kunyit selama waktu pengeringan dilakukan dengan menggunakan metode analisa oven dengan perlakuan untuk kunyit sebelum pengeringan dan sesudah pengeringan, yang didapatkan dengan Persamaan 1.

$\%$ kadar air $=\frac{\text { berat awal }- \text { berat akhir }}{\text { berat awal }} \times 100 \%$

Hubungan kadar air kunyit dengan waktu pengeringan dapat dilihat pada Gambar 3. Berdasarkan grafik pada Gambar 3, dapat dilihat bahwa waktu terbaik untuk pengeringan kunyit adalah 5 jam, dengan kadar air $8-10 \%$. Kadar air tersebut sudah mendekati nilai kadar air dalam SNI yaitu 5\% (Kusumaningrum et al., 2015).

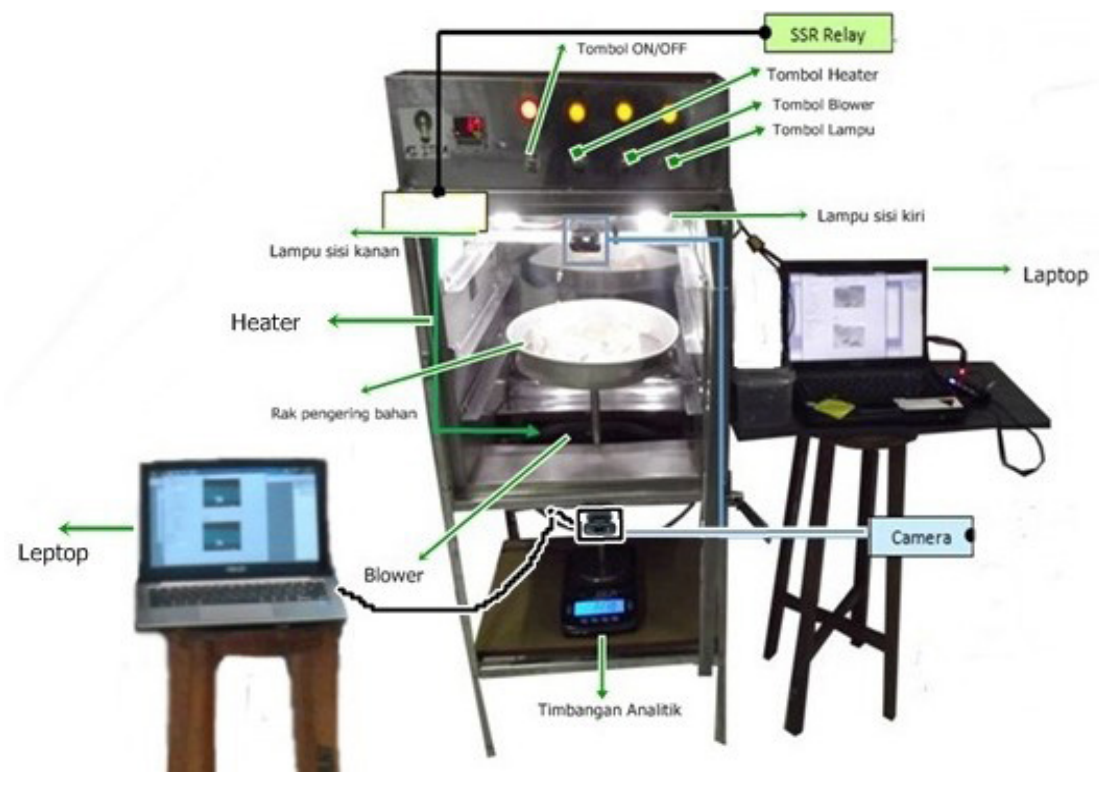

Gambar 1. Mesin pengering MI ITEM 
Jurnal Teknologi Pertanian Vol. 18 No. 1 [April 2017] 11-20

Pemodelan Pengeringan Kunyit (Curcuma domestica Val.) Berbasis Machine Vision [Zakaria dkk.]

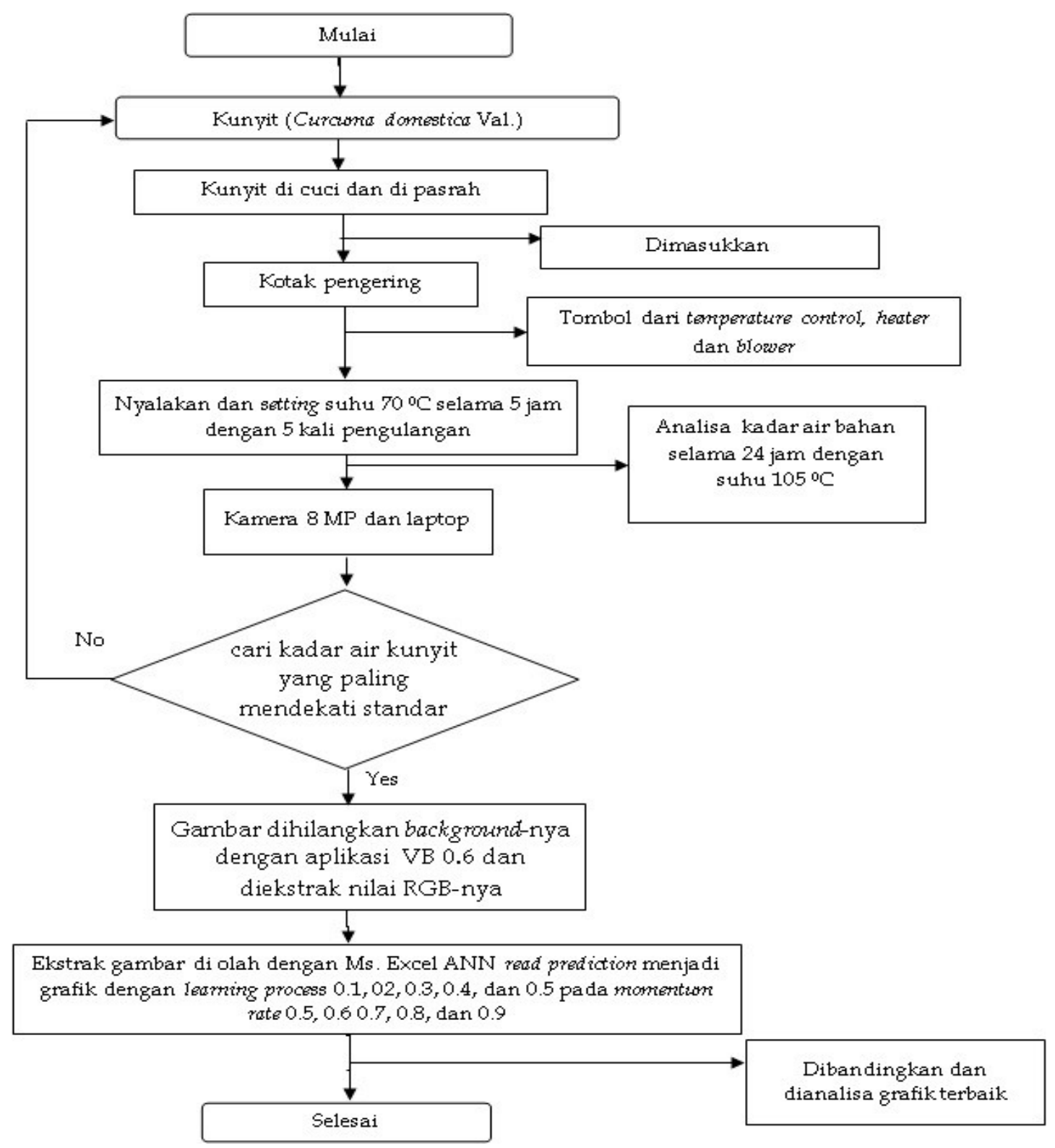

Gambar 2. Diagram alir proses kerja penelitian

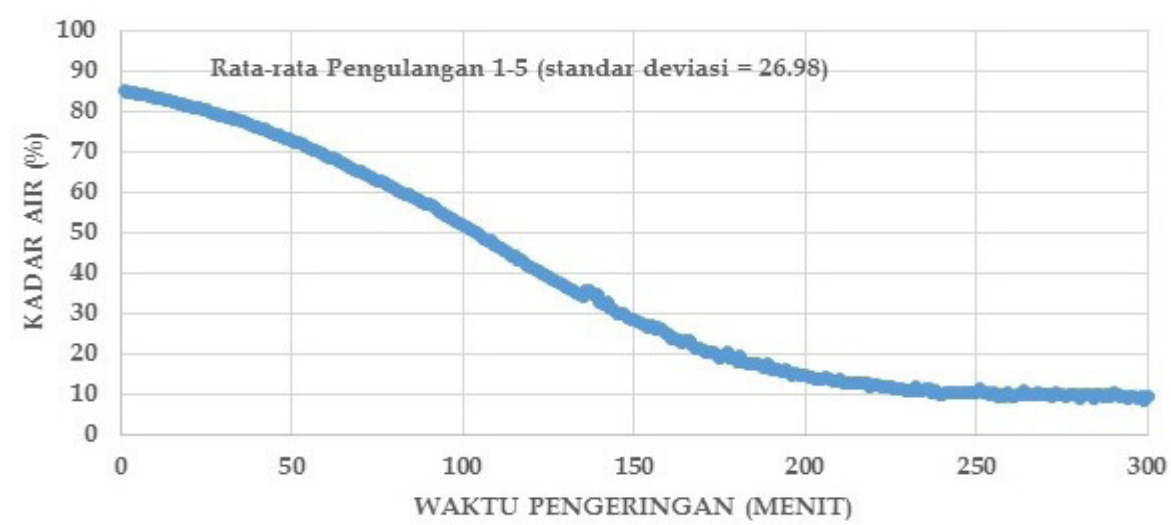

Gambar 3. Grafik hubungan kadar air kunyit dengan waktu pengeringan 


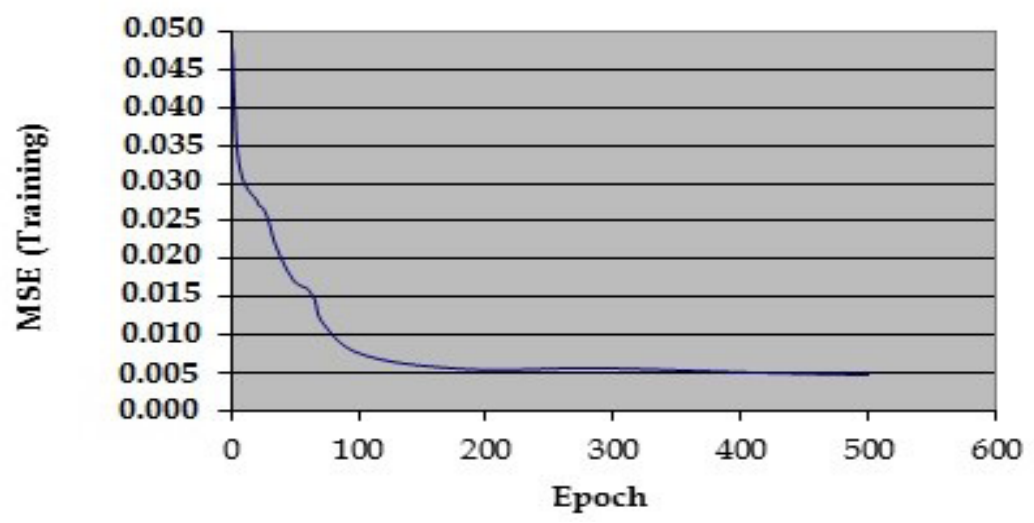

Gambar 4. Grafik ANN dengan MSE (training) terbaik

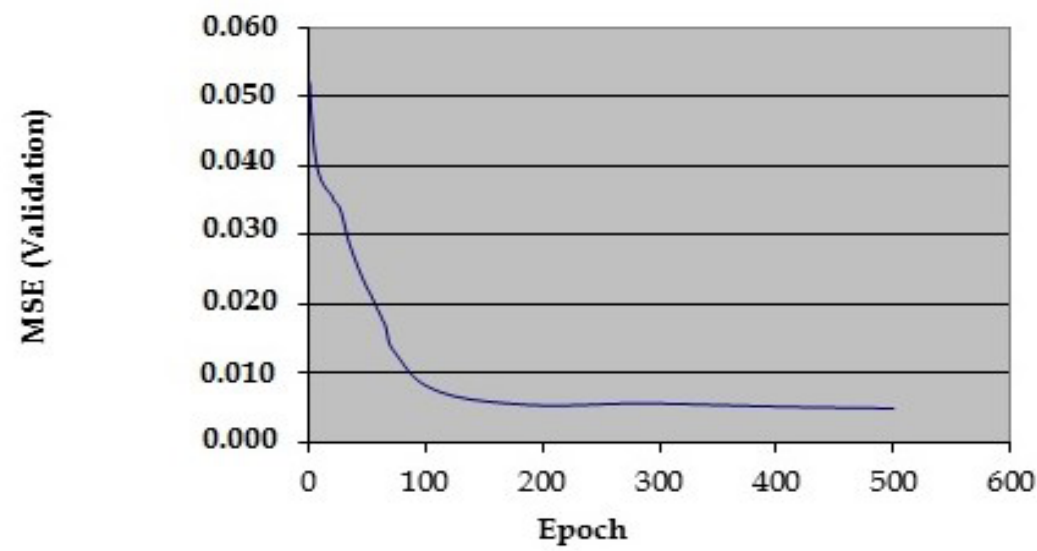

Gambar 5. Grafik ANN MSE (validasi) terbaik

(a)

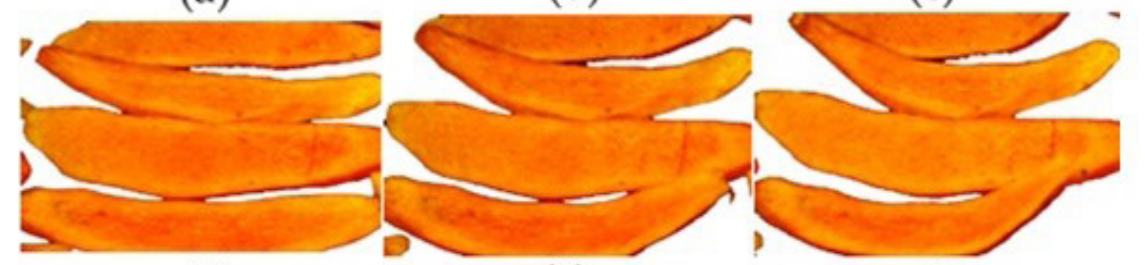

(d)

(e)

(f)

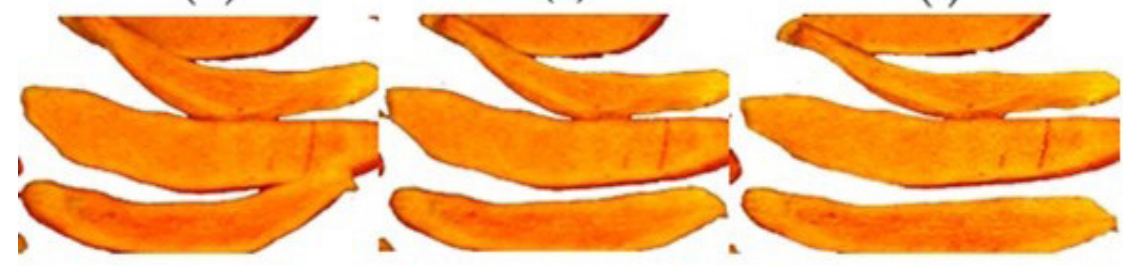

Gambar 6. Hasil Penampakan luaran pengeringan kunyit yang dipotong tipis $2 \mathrm{~mm}$ pada suhu $70{ }^{\circ} \mathrm{C}$ dengan lama waktu 0 menit (a), 10 menit (b), 20 menit (c), 30 menit (d), 40 menit (e), dan 50 menit (f) 
Jurnal Teknologi Pertanian Vol. 18 No. 1 [April 2017] 11-20

Pemodelan Pengeringan Kunyit (Curcuma domestica Val.) Berbasis Machine Vision [Zakaria dkk.]

\section{Pembuatan Grafik ANN dengan Indeks Warna RGB}

ANN didefinisikan sebagai suatu sistem pemrosesan informasi yang memiliki karakteristik menyerupai jaringan syaraf tiruan tercipta sebagai suatu generalisasi model matematis dari pemahaman manusia (human cognition) yang didasarkan atas asumsi sebagai berikut (Peschl 1993; Mason, 2003; Hermawan, 2006).

1. Pemrosesan informasi terjadi pada elemen sederhana yang disebut neuron

2. Isyarat mengalir di antara sel saraf/neuron
3. Setiap sambungan penghubung memiliki bobot yang bersesuaian

4. Setiap sel saraf akan merupakan fungsi aktivasi terhadap isyarat hasil penjumlahan berbobot yang masuk kepadanya untuk menentukan isyarat keluarannya

Cara untuk mendapatkan model ANN digunakan input RGB, yaitu model warna yang terdiri dari merah, hijau, dan biru, kemudian digabungkan dalam membentuk suatu susunan warna yang luas. Setiap warna dasar, misalnya merah, dapat diberi

Tabel 1. Data tabel learning rate dan momentum rate pada proses pembelajaran ANN

\begin{tabular}{|c|c|c|c|c|c|c|c|}
\hline \multirow{2}{*}{$\begin{array}{l}\text { Learning } \\
\text { Rate }\end{array}$} & \multirow{2}{*}{$\begin{array}{c}\text { Momentum } \\
\text { Rate }\end{array}$} & \multicolumn{2}{|c|}{ Training } & \multicolumn{2}{|c|}{ Validasi } & \multicolumn{2}{|c|}{ Hasil Grafik } \\
\hline & & MSE & ARE & MSE & ARE & Baik & Jelek \\
\hline \multirow{5}{*}{0.1} & 0.5 & 0.006 & $31.54 \%$ & 0.006 & $27.86 \%$ & & $\checkmark$ \\
\hline & 0.6 & 0.006 & $30.72 \%$ & 0.005 & $32.02 \%$ & $\checkmark$ & \\
\hline & 0.7 & 0.004 & $23.75 \%$ & 0.005 & $29.38 \%$ & & $\checkmark$ \\
\hline & 0.8 & 0.005 & $29.11 \%$ & 0.005 & $35.21 \%$ & & $\checkmark$ \\
\hline & 0.9 & 0.005 & $28.68 \%$ & 0.010 & $35.57 \%$ & $\checkmark$ & \\
\hline \multirow{5}{*}{0.2} & 0.5 & 0.004 & $25.10 \%$ & 0.005 & $21.92 \%$ & $\bar{\checkmark}$ & \\
\hline & 0.6 & 0.004 & $27.39 \%$ & 0.006 & $30.19 \%$ & $\checkmark$ & \\
\hline & 0.7 & 0.006 & $24.96 \%$ & 0.006 & $29.06 \%$ & & $\checkmark$ \\
\hline & 0.8 & 0.006 & $30.68 \%$ & 0.005 & $30.92 \%$ & & $\checkmark$ \\
\hline & 0.9 & 0.006 & $30.68 \%$ & 0.005 & $30.92 \%$ & & $\checkmark$ \\
\hline \multirow{5}{*}{0.3} & 0.5 & 0.004 & $30.55 \%$ & 0.003 & $26.00 \%$ & & $\sqrt{ }$ \\
\hline & 0.6 & 0.004 & $25.95 \%$ & 0.004 & $25.66 \%$ & & $\checkmark$ \\
\hline & 0.7 & 0.004 & $27.56 \%$ & 0.004 & $29.54 \%$ & & $\checkmark$ \\
\hline & 0.8 & 0.004 & $25.39 \%$ & 0.007 & $28.91 \%$ & & $\checkmark$ \\
\hline & 0.9 & 0.005 & $24.59 \%$ & 0.005 & $25.35 \%$ & $\checkmark$ & \\
\hline \multirow{5}{*}{0.4} & 0.5 & 0.005 & $26.95 \%$ & 0.004 & $18.65 \%$ & & $\bar{\checkmark}$ \\
\hline & 0.6 & 0.005 & $27.11 \%$ & 0.006 & $35.34 \%$ & & $\checkmark$ \\
\hline & 0.7 & 0.005 & $25.01 \%$ & 0.003 & $25.04 \%$ & & $\checkmark$ \\
\hline & 0.8 & 0.005 & $26.13 \%$ & 0.010 & $31.28 \%$ & & $\checkmark$ \\
\hline & 0.9 & 0.005 & $29.28 \%$ & 0.005 & $30.37 \%$ & $\checkmark$ & \\
\hline \multirow{5}{*}{0.5} & 0.5 & 0.005 & $27.19 \%$ & 0.004 & $34.05 \%$ & $\checkmark$ & \\
\hline & 0.6 & 0.005 & $23.72 \%$ & 0.007 & $21.21 \%$ & & $\checkmark$ \\
\hline & 0.7 & 0.005 & $27.83 \%$ & 0.004 & $28.29 \%$ & & $\checkmark$ \\
\hline & 0.8 & 0.005 & $29.06 \%$ & 0.005 & $27.36 \%$ & & $\checkmark$ \\
\hline & 0.9 & 0.006 & $29.80 \%$ & 0.005 & $26.33 \%$ & $\checkmark$ & \\
\hline
\end{tabular}


rentang nilai (Luc Buessler et al., 2014; Teimouri et al., 2014; Hayat et al., 2016; Leon Roque et al., 2016). Pada monitor komputer, nilai rentangnya paling kecil sebesar 0 , dan paling besar senilai 255. Pilihan skala 255 ini didasarkan pada cara mengungkap 8 digit bilangan biner yang digunakan oleh mesin komputer. Dengan cara ini, akan diperoleh total warna campuran sebanyak $255 \times 255$ $\times 255=16581375$ jenis warna. Sebuah jenis warna, dapat dibayangkan sebagai sebuah vektor diruang 3 dimensi yang biasanya dipakai dalam matematika, koordinatnya dinyatakan dalam bentuk tiga bilangan, yaitu komponen $\mathrm{x}$, komponen y dan komponen $\mathrm{z}$. Misalnya sebuah vektor dituliskan sebagai $r=$ $(\mathrm{x}, \mathrm{y}, \mathrm{z})$, untuk warna, komponen-komponen tersebut digantikan oleh komponen $\mathrm{R}(\mathrm{Red})$, G (Green), B (Blue), sehingga komposisi RGB menjadi warna $(30,75,255)$, putih $(255,255$, 255), dan hitam $(0,0,0)$.

Jumlah data 1500 dengan waktu pengeringan terbaik yaitu 5 jam. Membangun model ANN back propagation diperlukan momentum rate dan learning proses. Pada grafik nilai red, green, blue didapatkan nilai yang mendominasi yaitu nilai red. Pembuatan grafik ini dengan memasukkan nilai data dikalikan input (data RGB) yaitu 1 sampai 1500, dan nilai y (pixel) mulai 0 sampai 255, hidden layer sebanyak 2 hidden, jumlah node 20, output (y) berupa water content. Learning rate adalah metode pengenalan pola dengan jaringan saraf tiruan yang dilatih dengan seperangkat data untuk bisa mengenali dan mengidentifikasi pola data atau kurva, sehingga learning process menjadi bagian penting dalam metode ini. Pemilihan algoritma dan parameter yang bersesuaian dan penentuan berapa banyak perangkat data yang dibutuhkan dalam learning process sangat penting untuk menentukan akurasi dari peramalan yang dihasilkan (Pratt et al., 2008; Alfina, 2012; Bas et al., 2016; Xu, 2016).

Momentum rate adalah perubahan bobot yang didasarkan pada arah gradien pola terakhir dan pola sebelumnya (Hameed et al., 2016; Narayanan et al., 2016). Pada pembangunan jaringan backpropagation yang akan digunakan dalam perkiraan, hasil keputusan yang kurang memuaskan dapat diperbaiki dengan menggunakan learning rate dan momentum secara trial and error untuk mendapatkan nilai bobot yang optimum agar MSE jaringan dapat diperbaiki (Kusuma, 2011). Pada penelitian ini digunakan learning rate yaitu 0.1, 0.2, 0.3, 0.4 , dan 0.5 , untuk momentum rate yaitu 0.5 , $0.6,0.7,0.8$, dan 0.9 . Data tabel learning rate dan momentum rate pada proses pembelajaran ANN dapat dilihat pada Tabel 1.

\section{Hasil Grafik dari Momentum Rate dan Learning Rate Terbaik pada Model ANN}

Berdasarkan grafik yang telah dibuat, didapatkan model ANN terbaik adalah dengan menggunakan learning rate 0.3 dan momentum rate 0.9 . Pada 16 grafik terbaik MSE training dan validasi pada Gambar 4 dan Gambar 5, didapatkan dengan input learning rate dan momentum rate, yaitu kombinasi learning rate dan momentum rate yaitu 0.1 dan 0.6, 0.1, dan 0.9, 0.2 dan 0.5, 0.2, dan 0.6, 0.3, dan $0.9,0.4$ dan $0.9,0.5$ dan $0.5,0.5$ dan 0.9 . Hasil grafik ANN terbaik ditunjukkan pada learning rate 0.3 dan momentum rate 0.9 . Hal tersebut ditinjau dari sisi persentase nilai MSE 0.005 dengan ARE (\%) training 24.59\%, dan MSE 0.005 dengan ARE (\%) validasi 25.35\%, serta penentu yang paling terpenting adalah tingkat linieritas grafik yang dihasilkan oleh grafik MSE (training) dan grafik MSE (validasi) sebagai pembuatan model terbaik ANN. Pada penelitian ini belum dilakukan validasi terhadap model yang dihasilkan.

Hasil grafik ANN denganindeks warna RGB dengan kadar air pada jumlah data 1500 dan waktu pengeringan terbaik yaitu 5 jam, dapat digunakan untuk membangun model ANN backpropagation dengan menggunakan momentum rate dan learning process, sehingga hasil penampakan dari pengeringan dapat dilihat pada Gambar 6 .

\section{SIMPULAN}

Kadar air pada pengeringan kunyit (Curcuma domestica Val.) dengan suhu $70{ }^{\circ} \mathrm{C}$ selama 5 jam didapatkan hasil kadar air 5\%. Hal ini sudah sesuai dengan standar pengeringan kunyit sebesar 8-10\%. Pembuatan model ANN dilakukan dengan mengkombinasikan data input dengan learning rate $0.1,0.2,0.3,0.4$, dan 0.5 pada momentum rate $0.5,0.6,0.7,0.8$, dan 0.9. Hasil grafik ANN terbaik ditunjukkan pada learning rate 0.3 dan momentum rate 0.9 . ARE (\%) dan dicari MSE dengan nilai error paling rendah karena menunjukkan hasil grafik ANN terbaik ditinjau dari sisi persentase nilai ARE training 
Jurnal Teknologi Pertanian Vol. 18 No. 1 [April 2017] 11-20

Pemodelan Pengeringan Kunyit (Curcuma domestica Val.) Berbasis Machine Vision [Zakaria dkk.]

24.59\% dengan MSE 0.005, dan ARE (\%) validasi $25.35 \%$ dengan MSE 0.005. Model yang dibuat dapat disempurnakan dengan pemberian kombinasi learning rate dan momentum rate yang lengkap.

\section{DAFTAR PUSTAKA}

Adawyah, R. 2008. Pengolahan dan Pengawetan Ikan. Bumi Aksara, Jakarta

Alfina, O. 2012. Analisis Perbandingan Neural Network Backpropagation dengan Simple Perceptron dalam Mengenali Image Daun. Tesis. USU, Sumatera Utara

Asghari, G, A, Mostajeran, A, Shebli, M. 2009. Curcuminoid and essential oil components of turmeric at different stages of growth cultivated. Research in Pharmaceutical Sciences. 4(1):55-61

Asriyanti. 2013. Mempelajari Pembuatan Bumbu Inti Kunyit (Curcuma Domestica Val) Bubuk. Skripsi. Unhas. Sulawesi Selatan

Bas, E, Uslu, V, R, Egrioglu, E. 2016. Robust learning algorithm for multiplicative neuron model artificial neural networks. Expert Systems with Applications. 56:80-88

Boniglia, C, Aureli, P, Bortolin, E, Onori, S. 2009. Verification of imported food upon import for radiation processing: Dried herbs, including herbs used in food supplements, and spices by PSL and TL. Radiation Physics and Chemistry. 78:679-681

Borah, A, Hazarika, Khayer, S, M. 2015. Drying kinetics of whole and sliced turmeric rhizomes (Curcuma longa L.) in a solar conduction dryer. Information Processing in Agriculture. 2(2):85-92

Box, H. 1989. Developments in the spices trade: a Review. British Food Journal. 91(6):15-18

Chan, E, W, C, Lye, P, Y, Eng, S, Y, Tan, Y, P. 2013. Antioxidant properties of herbs with enhancement effects of drying treatments: a synopsis. Free Radicals and Antioxidants. 3(1):2-6

Dhanalakshmi, K, Bhattacharya, S. 2014. Agglomeration of turmeric powder and its effect on physico-chemical and microstructural characteristics. Journal of Food Engineering. 120:124-134
Fadilah, Distantina, S, Pratiwi, D, B, Muliapakarti, R, Danarto, Y, C, Wiratni, Fahrurrozi, M. 2010. Pengaruh metode pengeringan terhadap kecepatan pengeringan dan kualitas karagenan dari rumput laut Eucheuma cottonii. Prosiding Seminar Rekayasa Kimia dan Proses, Universitas Diponegoro, Semarang, pp. 1-6

Hameed, A, A, Karlik, B, Salman, M, S. 2016. Back-propagation algorithm with variable adaptive momentum. KnowledgeBased Systems. 114:79-87

Harsha, M, R, Prakash, S, V, C, Dharmesh, S, M. 2016. Modified pectic polysaccharide from turmeric (Curcuma longa): A potent dietary component against gastric ulcer. Carbohydrate Polymers. 138:143-155

Hayat, M, Bennamoun, M, El-Salam, A, A. 2016. An RGB-D based image set classification for robust face recognition from Kinect data. Neurocomputing. 171:889-900

Hee Kim, J, Jeong Yang, H, Jae Kim, Y, Park, S, Hee Lee, O, Kim, K, S, Kim, M, J. 2016. Korean turmeric is effective for dyslipidemia in human intervention study. Journal of Ethnic Foods. 3(3):213221

Hermawan, A. 2006. Jaringan Syaraf Tiruan. Penerbit Andi, Yogyakarta

Hmar, B, Z, Kalita, D, Srivastava, B. 2017. Optimization of microwave power and curing time of turmeric rhizome (Curcuma Longa L.) based on textural degradation. LWT-Food Science and Technology. 76:48-56

Khalili, K, Bagherian, M, Khisheh, S. 2014. Numerical Simulation of Drying Ceramic Using Finite Element and Machine Vision. Procedia Technology. 12:388-393

Khazaei, N, B, Tavakoli, T, Ghassemian, H, Khoshtaghaza, M, H, Banakar, A. 2013. Applied machine vision and artificial neural network for modeling and controlling of the grape drying process. Computers and Electronics in Agriculture. 98:205-213

Kusuma, I, W, Abadi, A, M. 2011. Aplikasi model backpropagation neural network untuk perkiraan produksi tebu pada pt perkebunan nusantara IX. Prosiding Seminar Nasional Matematika dan Pendidikan Matematika, UNY, Yogyakarta, pp. $97-108$ 
Kusumaningrum, H, P, Kusdiyantini, E, Pujiyanto, S. 2015. Kualitas simplisia tanaman biofarmaka Curcuma domestica setelah proses pemanasan pada suhu dan waktu bervariasi. Bioma. 17(1):2733

Lee Yue, G, G, Kwok, H, F, Ming Lee, J, K, Jiang, L, Wai Wong, E, C, Gao, S, Lok Wong, H, Li, L, Man Chan, K, Chung Leung, P, Pui Fung, K. 2016. Combined therapy using bevacizumab and turmeric ethanolic extract (with absorbable curcumin) exhibited beneficial efficacy in colon cancer mice. Pharmacological Research. 111:43-57

Leon Roque, N, Abderrahim, M, Nunez Alejos, L, Arribas, S, M, Condezohoyos, L. 2016. Prediction of fermentation index of cocoa beans (Theobroma cacao L.) based on color measurement and artificial neural networks. Talanta. 161:3139

Lorentzen, G, Breiland, M, S, W, Ostli, J, Wang Andersen, J, Olsen, R, L. 2015. Growth of halophilic microorganisms and histamine content in dried saltcured cod (Gadus morhua L.) stored at elevated temperature. LWT-Food Science and Technology. 60(1):598-602

Luc Buessler, J, Smagghe, P, Phillippe Urban, J. 2014. Image receptive fields for artificial neural networks. Neurocomputing. 144:258-270

Man, S, Chai, H, Qiu, P, Liu, Z, Fan, W, Wang, J, Gao, W. 2015. Turmeric enhancing anti-tumor effect of Rhizoma paridis saponins by influencing their metabolic profiling in tumors of H22 hepatocarcinoma mice. Pathology-Research and Practice. 211(12):948-954

Mason, R, O. 2003. Ethical issues in artificial intelligence. Encyclopedia of Information Systems. 239-258

Morgan, C, A, Herman, N, White, P, A, Vesey, G. 2006. Preservation of micro-organisms by drying; a review. Journal of Microbiological Methods. 66(2):183-193

Nadian, M, H, Abbaspour-Fard, M, H, Martynenko, A, Golzarian, M, R. 2017. An intelligent integrated control of hybrid hot air-infrared dryer based on fuzzy logic and computer vision system. Computers and Electronics in Agriculture. 137:138-149

Narayanan, S, J, Bhatt, R, B, Perumal, B. 2016. Improving the accuracy of fuzzy deci- sion tree by direct back propagation with adaptive learning rate and momentum factor for user localization. Procedia Computer Science. 89:506-513

Peschl, M, F. 1993. Knowledge representation in cognitive systems and science: In search of a new foundation for philosophy of science from a neurocomputational and evolutionary perspective of cognition. Journal of Social and Evolutionary Systems. 16(2):181-213

Plotto, A. 2004. Turmeric : post - production Management. Dilihat 7 Februari 2017. <http://www.fao.org/3/a-ax446e. pdf $>$

Prasad, J, Vijay, V, K, Tiwari, G, N, Sorayan, V, P, S. 2006. Study on performance evaluation of hybrid drier for turmeric (Curcuma longa L.) drying at village scale. Journal of Food Engineering. 75(4):497-502

Pratt, M, A, Konda, S, Chu, C, H, H. 2008. Texture-based image steganalysis by artificial neural networks. International Journal of Intelligent Computing and $\mathrm{Cy}$ bernetics. 1(4):549-562

Rahayu,H, D, I. 2010. Pengaruh Pelarut Yang Digunakan Terhadap Optimasi Ekstraksi Curcumin pada Kunyit (Curcuma Domestica Val.). Skripsi. UMS. Surakarta

Sangwan, A, Kawatra, A, Sehgal, S. 2012. Nutrient composition of mint powder prepared from various drying methods. Nutrition E Food Science. 42(1):2125

Schaarschmidt, S. 2016. Public and private standards for dried culinary herbs and spices - part I: standards defining the physical and chemical product quality and safety. Food Control. 70:339-349

Shin, H, S, See, H, J, Jung, S, Y, Choi, D, W, Kwon, D, A, Bae, M, J, Sung, K, S, Shon, D, H. 2015. Journal of Ethnopharmacology. 175:21-29

Siallagan. B. 2009. Kajian Proses Pengeringan Kemoreaksi Jahe Dengan Kapur Api (CaO). Skripsi. USU, Sumatera Utara

Syukur, C. 2010. Turina, varietas unggul kunyit kurkumin tinggi. Dilihat 6 Februari 2016. <http://pustaka.litbang. pertanian.go.id/inovasi/kl10111.pdf>

Teimouri, N, Omid, M, Mollazade, K, Rajabipour, A. 2014. A novel artificial neural networks assisted segmentation algorithm for discriminating almond nut 
Jurnal Teknologi Pertanian Vol. 18 No. 1 [April 2017] 11-20

Pemodelan Pengeringan Kunyit (Curcuma domestica Val.) Berbasis Machine Vision [Zakaria dkk.]

and shell from background and shadow. Computers and Electronics in Agriculture. 105:34-43

Trujillo, J, Chirino, Y, I, Moliana-Jijon, E, Anderica-Romero, A C, Tapia, E T, Pedraza-Chaverri, J. 2013. Renoprotective effect of the antioxidant curcumin: recent findings. Redox Biology. 1(1):448456

WWF. 2009. Hutan indonesia: penyerap atau pelepas emisi gas rumah kaca?. Dilihat 20 Januari 2017. <http://d2d2tb15kqhejt.cloudfront.net/downloads/ lembar_fakta_deforestasi_tanpa_foto. pdf $>$

Xie, Y, Gao, Z, Liu, Y, Xiao, H. 2017. Pulsed vacuum drying of rhizoma dioscoreae slices. LWT-Food Science and Technology. 80:237-249

$\mathrm{Xu}, \mathrm{J}$, L, Sun, D, W. 2017. Identification of freezer burn on frozen salmon surface using hyperspectral imaging and computer vision combined with machine learning algorithm. International Journal of Refrigeration. 74:151-164

Xu, Y, Y. 2016. Multiple-instance learning based decision neural networks for image retrieval and classification. Neurocomputing. 171:826-836

Yao, Y. 2016. Enhancement of mass transfer by ultrasound: Application to adsorbent regeneration and food drying/ dehydration. Ultrasonics Sonochemistry. 31:512-531 